ball, pistols and bullets, continually obtrude themselves. It can fairly be said that one to whom such analogies appeal could derive little benefit from the rest of the book; and those who find the book at their own level must be irritated by these sudden intrusions.

To summarize, then, one might say that this would have been a much better book had its scope been less. On the technicalities of X-rays it is good, and the large number of references to original work should make it extremely useful. But those sections with which the author is presumably unfamiliar should have been omitted.

H. LIPSON

$|0|=$

\section{ORGANISATION OF AGRICULTURE}

\section{Farming and Mechanised Agriculture}

Edited by Sir George Stapledon. Pp. 492. (London and Ne York : Todd Publishing Co. Ltd., 1946.) 21s. ndt?

$\mathrm{T}$ HIS andial reference book, now in its third editi provides a conspectus of the organisation of agricultu $\theta$ in the United Kingdom. Farmers are well amè, Drhaps painfully aware, of the complexity of this organisation; but the reader who has no promsional contact with agriculture may well be surprised at the number of official and private bodies which exist to control or develop different parts of the industry. Ten Ministries or Departments, and twentyeight statutory bodies with numerous committees, the work of which is concerned in varying degree with agriculture, are listed in addition to thirtyfive national societies or associations and many local ones. According to the point of view of the reader, these figures may be taken as a striking illustration of the size and importance of the agricultural industry, and the diversity of its products, or as an example of the insidious growth of bureaucracy.

The book begins with a series of articles covering a wide field, ranging from the world supply of food and timber to the chemical control of weeds. The purpose of this section is not clear from its contents; if it was intended to present $a_{0}$ comprehensive view of the present state and current problems of agriculture, the selection of subjects is not a well-balanced one; for example, two of the articles, by members of the same branch of the U.S. Department of Agriculture, deal with closely related topics. This section is likely to be of more interest to the general reader than to the agriculturist, for the subjects have been fully discussed in many recent articles in the technical Press, and in books, in some cases by the same authors. It is followed by a short section on legislation and policy.

The middle section consists of directories of the official bodies concerned with agricultural administration, including some in the Dominions and the United States, statements of the objects and policy of these bodies and of private organisations and officially appointed committees, an account of the organisation of agricultural education, a directory of educational and research institutions and a directory of organisations interested in farming and mechanized agriculture. This is perhaps the most useful part of the book, for the information which it contains is not all available in any other single publication. Some small changes in arrangement might make consultation easier; for example, the laboratories directly controlled by the Ministry of
Agriculture, the Department of Scientific and Industrial Research and the Agricultural Research Council are not included in the directory of research institutions but appear earlier, in the official directories.

Later sections give tables of statistics of agricultural production, a list of books, periodicals and films on agricultural subjects, a "Who's Who in Farming and Mechanised Agriculture", and a subject index. There are a number of obvious omissions from the "Who's Who", as well as some scarcely justifiable inclusions, and in future editions it would be preferable to replace this section by an index of names referred to earlier in the text.

Two general criticisms may be made : first, the title is misleading, for the book contains little information on the practice of husbandry, and still less on mechanization; secondly, the book is unnecessarily well made and the price too high for an ephemeral work which is to be renewed annually.

\section{J. WATSON}

\section{THE STORY OF LEATHER $\%$ : \\ Leather in Life, Art and Industry}

Being an Outline 1 Preparation and Uses in Britain Yesterday add Po-day, together with some Reflexions on its Pldce in the World of Synthetics To-morrow. By John W. Waterer. Pp. $320+111$ plates. (Londo: Faber and Faber, Ltd., 1946.) 50s. net.

$\mathrm{N}$

W NERER has written a remarkable and a V aryidating book. It should be read not only by all ho have any connexion, however remote, wipheather and leather goods, but also by all who tak an interest in the social and industrial history of Great Britain. Mr. Waterer has a knowledge of his subject that only first-hand experience can give, and, more than this, he writes with the fervour that springs from advocating a worth-while cause, namely, that in these days of factory production a study of industrial design can ensure that meetness of material, form and purpose which existed in the days of the old craftsman who carried through the making of an object from start to finish with his own hands and brains.

The making of leather and leather goods is one of England's oldest industries, and one of the first to achieve the distinction of an export trade. Over the centuries the reputation of certain English leather goods was built up, so that even to-day things like English saddles and sports goods, certain classes of luggage, and men's shoes are still regarded as the best that can be made. This aiming at a high standard of quality was achieved in the early middle ages by the efforts of the trade guilds, of which about a dozen were connected with articles of leather, with six surviving to this day though no longer exercising supervision over the crafts they nominally represent.

About a third of Mr. Waterer's book is devoted to the leather guilds and crafts. The story of the guilds is not unamusing - founded to protect the interests of the members, all of whom were originally active participants in the crafts concerned, and to maintain a high standard of quality in the wares offered to the public, they soon allowed these high moral principles to give way to ordinary human nature, and we find them quarrelling with each other over spheres of influence (even to actual bloodshed), opposing the employment of foreign political refugees, and making 